\title{
PENOLAKAN UMAT TERHADAP RISALAH KENABIAN DAN RELEVANSINYA DENGAN PENOLAKAN MUSLIM TERHADAP UNDANG-UNDANG PERKAWINAN
}

\author{
Khoiruddin Nasution \\ Universitas Islam Negeri Sunan Kalijaga Yogyakarta \\ Email: knasut@gmail.com \\ DOI: 10.37876/adhki.v2i1.26
}

\begin{abstract}
The people reject the prophetic treatise, just as some Indonesian people reject the enactment of Law No.1 of 1974 on Marriage (UUP). The question is whether there is relevance between these two objections. The results of research show there is relevance between the two. The relevance found was that both were rejected because they brought a change. People reject change, the same as some Indonesian society also rejects change. The people want establishment, the same as some Indonesian want establishment. The background of rejection is lack of understanding of the changes brought about. So the task of the prophets throughout his life is to understand the people. Most of the prophets succeeded in understanding and finally the people accepted the message of the prophetic message, but some were not understood. In line with the duties of the prophets, the task of observers, thinkers, and experts in Indonesian Islamic Family Law is to understand Indonesian society about the status of the UUP. That the UUP and related regulations are Indonesian Islamic sharia. That the UUP and related regulations are Indonesian Islamic law. That the UUP and related regulations are the same status as fiqh, fatwa, jurisprudent and interpretation, both the results of ijtihad, both the results of thought, are equally the results of understanding nash (istinbath). Even the UUP is actually a result of collective thought (ijmâ), while fiqh, fatwa, jurisprudence are the result of individual thought (ijtihad fardi). Although there is a collective fatwa, the number of mujtahids involved is still very limited compared to the experts involved in formulating and stipulating UUP.
\end{abstract}

Keywords: the prophetic treatise, Marriage Law, rejection, collective thought (ijmâ), individual thought (individual ijtihad)

\begin{abstract}
Abstrak
Umat menolak risalah kenabian, sama dengan masyarakat Indonesia ada yang menolak kehadiran dan penetapan Undang-Undang No.1 tahun 1974 tentang Perkawinan (UUP). Pertanyannya adalah apakah ada relevansi antara dua penolakan ini. Ternyata hasil menelitian menunjukkan ada relevansi antara keduanya. Relevansi yang ditemukan adalah dua-duanya ditolak karena membawa ajakan perubahan. Umat menolak perubahan, sama dengan masyarakat Indonesia juga menolak perubahan. Umat menginginkan kemapanan, sama dengan masyarakat Indonesia menginginkan kemapanan. Latar belakang penolakan adalah kurang atau tidak paham akan perubahan yang dibawa. Maka tugas para nabi sepanjang hidupnya adalah memahamkan umat. Sebagian besar nabi berhasil memahamkan dan akhirnya umat menerima pesan risalah kenabian, tetapi ada juga yang tidak berhasil dipahamkan. Sejalan dengan tugas para nabi, maka tugas para peminat, pemerhati, pemikir, dan pakar Hukum Keluarga Islam Indonesia adalah memahamkan masyarakat Indonesia akan status UUP. Bahwa UUP dan peraturan terkait adalah syariah Islam Indonesia. Bahwa UUP dan peraturan terkait adalah hokum Islam Indonesia. Bahwa UUP dan peraturan terkait sama statusnya dengan fikih, fatwa, yurispruden dan tafsir, sama-sama hasil ijtihad, sama-sama hasil pemikiran, sama-sama hasil istinbath hokum. Bahwa UUP malah merupakan ijma', sementara fikih, fatwa, yurisprudensi adalah hasil ijtihad individu (fardi). Meskipun ada fatwa kolektif, tetapi jumlah mujtahid yang terlibat tetap sangat terbatasi dibandingkan dengan ahli yang terlibat dalam merumuskan dan menetapkan UUP.
\end{abstract}

Kata kunci: risalah kenabian, UUP, penolakan, ijmâ', ijtihad individu. 


\section{Pendahuluan}

Ada sejumlah ayat dalam al-Qur'an yang mengambarkan penolakan umat terhadap risalah kenabian; visi, misi dan ajaran yang dibawa para nabi (risalah kenabian dari kata nabi atau kerasulan dari kata rasul). Kata nabi dari bahasa arab naba, berarti warta (al-khabar), berita, informasi, laporan. ${ }^{1}$ Dalam bentuk transitif (anba'a) berarti memberi informasi (to inform), meramal (to predict), menceritakan masa depan (to forecell). Adapun nubuwah merupakan kata benda (bentuk masdar) dari naba' berarti kenabian (prophecy), ramalan (prophethood). ${ }^{2}$

Sementara kata risalah dalam al-Qur'an ditemukan 10 kali dan dimuat dalam 5 surah. Ayat-ayat dimaksud adalah 1.al-Maidah (5); 67, ${ }^{3}$ 2.al-Anam (6); 124, ${ }^{4}$ 3.al-Araf (7): $62,{ }^{5} 68,{ }^{6} 79,7^{7} 93^{8}$ dan 144, ${ }^{9}$ 4.al-Ahzab (33): 39, ${ }^{10}$ 5.al-Jin (72): $23^{11}$ dan $28 . .^{12}$

Isi pesan yang dibawa para nabi dapat dikelompokkan menjadi dua, yakni pesan yang dibawa para nabi dan pesan yang dibawa nabi Muhammad saw. Isi pesan para nabi diperdebatkan para ahli. Ada yang menyebut para nabi menyampaikan ajakan menyembah Tuhan Yang Maha Esa (monotheis). Menurut Murtadha Muthohhari, dengan merujuk kepada al-Qur'an menyebut dua pesan risalah kenabian. Pertama, mengakui eksistensi Tuhan Yang Maha Esa dan mendekatkan diri kepadaNya, sesuai dengan ayat dalam surah al-Ahzab (45-46). ${ }^{13}$ Kedua, meniscayakan tegaknya keadilan, sebagaimana disebut dalam surah al-Hadid (75): $25 .{ }^{14}$

\footnotetext{
${ }^{1}$ Lisan al-'Arab, Abdullah ibn Mandhur (Beirut: Dâr al-Sadir, t.t.), VI: 561.

${ }^{2}$ Kamur Besar Bahasa Indonesia, Tim Perumus, ed ke-2 (Jakarta: Balai Pustaka, 1994), hlm. 679.

${ }^{3}$ Al-Maidah (5): 67;

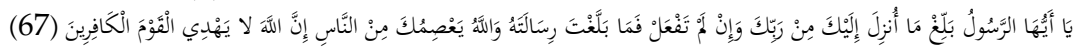

${ }^{4}$ al-Anam (6); 124;

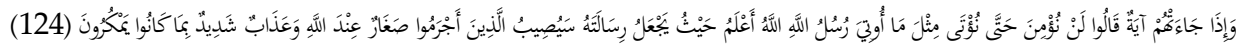

5 al-Araf (7): 62;

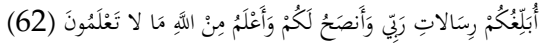

${ }^{6}$ Al-Araf (7): 68;

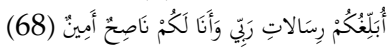

7 al-Araf (7): 79;

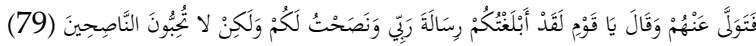

8 al-Araf (7): 93;

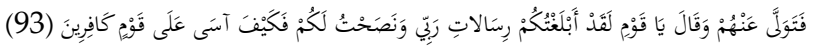

99 al-Araf (7): 144;

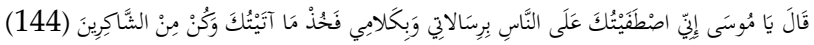

10 al-Ahzab (33): 39

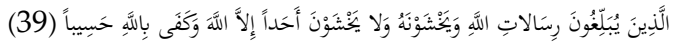

11 al-Jin (72): 23 dan 28

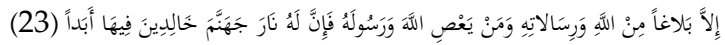

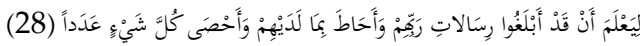

12 Hamim Ilyas, "Islam Risalah Rahmat dalam al-Qur'an (Tafsir Q.S. Al-Anbiya (21):107", Hermeneia: Jurnal Kajian Islam Interdisipliner, Vol. 6, No. 2 (Juli-Desember 2017).

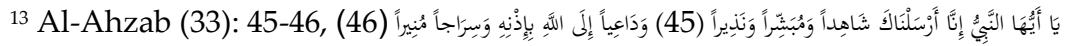

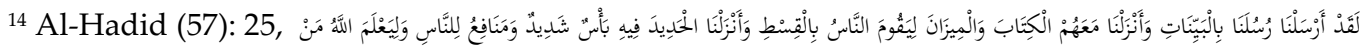

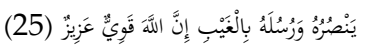


Kemudian Murtadha menyebut misi pertama sebagai monotheisme teoritis dan bersifat praktis individual, sementara misi kedua sebagai monotheisme yang bersifat

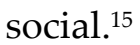

Bagaimana hubungan antara dua misi risalah tersebut muncul tiga model. Pertama, para nabi memiliki tujuan ganda yang berdiri sendiri dalam penyampaiannya. Satu sisi berkait dengan kehidupan dan kebahagiaan akhirat yang bersifat subjektif (monotheis teoritis dan praktis yang bersifat individual). Sedangkan di sisi lain misi kenabian juga terkait dengan kehidupan dan kebahagiaan dunia (monotheisme praktis social). Kedua, tujuan misi kenabian adalah monotheisme praktis social, yang syarat utamanya adalah monotheisme teoritis dan praktis individual. Menurut model ini kesempurnaan manusi terletak pada bagaimana seseorang mampu mengubah dirinya dari 'aku' menjadi 'kami'. Model ketiga, misi utama risalah kenabian adalah monotheisme teoritsi dan praktis individual dalam bentuk peniscayaan pengenalan dan pendekatan manusia pada Tuhannya. Posisi monotheis social menjadi prasyarat dan sarananya. Maka untuk kesempurnaan manusia dalam dirinya harus menyatu nilai-nilai social seperti keadilan, kemerdekaan, kesederhanaan, kesamaan, toleransi, demokrasi, dan segala sifa dan moralitas social.

Sementara isi pesan yang dibawa nabi Muhammad saw juga diperdebatkan. Ada yang menyebut isi pesan nabi Muhammad saw adalah rahmat, berdasarkan pada al-Qur'an surah al-Anbiya (21): $107 .{ }^{16}$ Ada yang menyebut untuk penyempurnaan akhlak, sebagaimana disebut dalam hadis.

Adapun tujuan nabi diutus kepada umat manusia adalah peringatan, penyampaian berita gembira dan pemutus, seperti dijelaskan dalam al-Baqarah (2): 213. ${ }^{17}$

Sejumlah studi bidang kenabian ditulis sejumlah peneliti. Di antaranya adalah hasil penelitian Eni Zulaiha, dengan focus bahasan pengertian nabi dan kenabian dalam al-Qur'an dan hadis. ${ }^{18}$ Penelitian berikutnya adalah karya Siti Malaiha Dewi, ${ }^{19}$ penelitian yang bertujuan menunjukkan bahwa misi risalah kenabian Muhammad saw bersifat universal untuk semua manusia, tidak hanya untuk mereka yang beriman, tetapi juga bagi mereka yang tidak beriman. Rahmat cerminan Islam yang dibawa

${ }^{15}$ Murtadha Muthohhari, Falsafah Kenabian, terj. Ahsin Muhammad, cet ke-1 (Jakarta: Pustaka Risalah, 1991), hlm. 30.

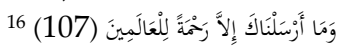

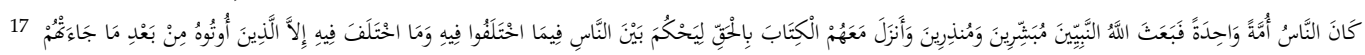

Artinya: Manusia itu adalah umat yang satu. (Setelah timbul perselisihan), maka Allah mengutus para nabi sebagai pemberi kabar gembira dan pemberi peringatan, dan Allah menurunkan bersama mereka Kitab dengan benar, untuk memberi keputusan di antara manusia tentang perkara yang mereka perselisihkan. Tidaklah berselisih tentang Kitab itu melainkan orang yang telah didatangkan kepada mereka Kitab, yaitu setelah datang kepada mereka keterangan-keterangan yang nyata, karena dengki antara mereka sendiri. Maka Allah memberi petunjuk orang-orang yang beriman kepada kebenaran tentang hal yang mereka perselisihkan itu dengan kehendak-Nya. Dan Allah selalu memberi petunjuk orang yang dikehendaki-Nya kepada jalan yang lurus.

${ }^{18}$ Eni Zulaiha, "Fenomena Nabi dan Kenabian dalam Perspektif Alquran", dalam Al-Bayan: Jurnal Studi Al-Qur'an dan Tafsir 1, 2 (Desember 2016), hlm. 149-164.

19 Siti Malaiha Dewi, "Kontektualisasi Misi Risalah Kenabian dalam Menangkal Radikalisme", FIKRAH: Jurnal Ilmu Aqidah dan Studi Keagamaan, Volume 3, No. 2, (Desember 2015), hlm. 349-369. 
Nabi Muhammad saw adalah rahmat dan kasih sayang yang ramah, santun, toleran, dan penuh dengan cinta damai. Islam tidak menebarkan kebencian dan permusuhan. Abdul Hakim Siregar, ${ }^{20}$ dalam karyanya mengkaji, menganalisa eksistensi jiwa manusia yang meliputi; sifat, hakikat, martabat, jiwa serta maqam-maqam jiwa manusia. Demikian juga gejala jiwa manusia, meliputi; perilaku, sikap, tindakan, penampilan, dan gerak-gerik diri manusia yang telah melaksanakan evolusi dan transpormasi diri melalui pemahaman dan pengamalan agama secara totalitas berdasarkan wahyu dan ketauladanan Rasulullah Muhammad saw. Selanjutnya Karya Salamah Noorhidayati ${ }^{21}$ mengurai bagaimana konsep nabi dan karakteristiknya secara umum, bagaimana relasi perempuan dan wahyu, bagaimana perbedaan pandangan ulama, khususnya ahli tafsir terkait dengan status Maryam dan argument al-Qur'an bagi penetapan Maryam sebagai bagian dari mata rantai nabi dalam perspektif tafsir yang berkeadilan jender. Karya Arif Nuh Safri, ${ }^{22}$ bermaksud menunjukkan bahwa memahami kerahmatan yang dipraktekkan oleh Nabi yang bersifat universal jauh lebih penting daripada sekedar mengikuti Nabi dalam ranah simbolik semata. Sementara tulisan ini focus pada deskripsi alasan-alasan menolakan umat terhadap risalah kenabian, dan bagaimana relevansi penolakan risalah kenabian ini terhadap respon negative muslim Indonesia terhadap Undang-Undang Perkawinan No. 1 tahun 1974 (UUP) dan peraturan perundang-undangan yang relevan. Sistematika tulisan adalah dituliskan ayat-ayat al-Qur'an yang berisi penolakan terhadap risalah kenabian, setelah latar belakang. Bagian berikutnya adalah deskripsi alasan penolakan lahir dan ditetapkannya UUP. Sebelum kesimpulan ditulis relevansi antara penolakan terhadap risalah kenabian dari umat dan alasan penolakan UUP dari masyarakat Indonesia.

\section{Ayat-Ayat Penolakan terhadap Risalah Kenabian}

Penolakan terhadap risalah kenabian atau kerasulan dapat dikelompokkan berdasarkan sejarah hidup para nabi dan/atau rasul. Misalnya dapat kelompokkan menjadi 1. kisah nabi Nuh AS., 2. kisah nabi Ibrahim AS., dan 3. kisah nabi Musa AS. Namun masih banyak juga kisah nabi yang menceriterakan penolakan umat.

Pertama, kisah penolakan risalah nabi Nuh AS., oleh umatnya disebutkan dalam al-Qur'an surah al-Hud (11); 25-27. ${ }^{23}$ Inti risalah yang dibawa nabi Nuh AS

${ }^{20}$ Abdul Hakim Siregar, "Psikologi Kenabian Dalam Menghidupkan Kepribadian Diri", Wahana Inovasi, Vol.3 No.2 (Juli-Des 2014), hlm. 274-287.

21 Salamah Noorhidayati, "Menguak Fakta Kenabian Maryam AS", YIN YANG. Vol. 9 No. 1 (Januari-Juni 2014), hlm. 19-36.

22 Arif Nuh Safri, “Otentisitas Risalah Kenabian (Pluralisme dan Kemanusiaan)”, ESENSIA: Jurnal FUPI, UIN Suka Yogyakarta, Vol. XIII No. (1 Januari 2012), hlm. 167-186.

${ }^{23}$ al-Hud (11); 25-27;

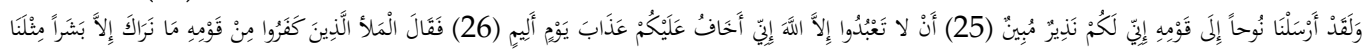

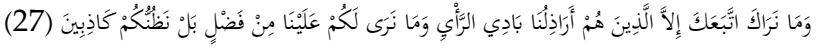

Artinya: Dan sesungguhnya Kami telah mengutus Nuh kepada kaumnya, (dia berkata): "Sesungguhnya aku adalah pemberi peringatan yang nyata bagi kamu. agar kamu tidak menyembah selain Allah. Sesungguhnya aku khawatir kamu akan ditimpa adzab (pada) hari yang sangat menyedihkan". Maka berkatalah pemimpin-pemimpin yang kafir dari kaumnya: "Kami tidak melihat kamu, melainkan (sebagai) seorang manusia (biasa) seperti kami, dan kami tidak melihat orang-orang yang mengikuti kamu melainkan orang-orang yang hina dina di antara kami yang lekas percaya saja, dan 
adalah larangan menyembah selain Allah, dan perintah menyembah hanya Allah. Sementara alasan penolakan dari umatnya adalah karena umat melihat nabi Nuh AS sebagai manusia biasa, tidak mempunyai kelebihan, bahkan seorang yang hina. Inti yang sama disebut juga di surah al-Mumin (23): 23-27. ${ }^{4}$

Kedua, Kisah penolakan risalah nabi Ibrahim AS., oleh umatnya disebutkan dalam surah Maryam (19): 42-48. ${ }^{25}$ Ketika Ibrahim bertanya kepada bapaknya dan kaumnya mengapa setia menyembah patung. Mereka jawab karena bapak kami melakukannya, sebagaimana disebut dalam surah al-Anbiya (21);52 dan 53. ${ }^{26}$ Jadi, umat nabi Ibrahim menolak karena bapak dan nenek moyang mereka melakukannya.

kami tidak melihat kamu memiliki sesuatu kelebihan apa pun atas kami, bahkan kami yakin bahwa kamu adalah orang-orang yang dusta".

24 al-Mumin (23): 23-27.

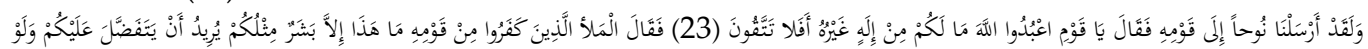

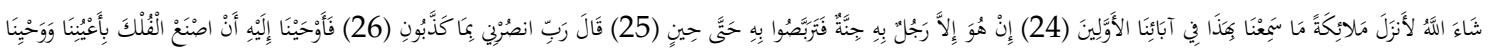

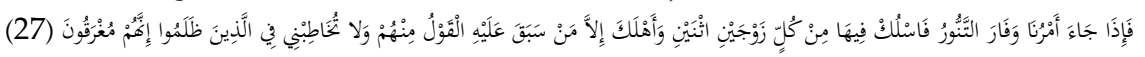

Artinya: Dan sesungguhnya Kami telah mengutus Nuh kepada kaumnya, lalu ia berkata: "Hai kaumku, sembahlah oleh kamu Allah, (karena) sekali-kali tidak ada Tuhan bagimu selain Dia. Maka mengapa kamu tidak bertakwa (kepada-Nya)?". Maka pemuka-pemuka orang yang kafir di antara kaumnya menjawab: "Orang ini tidak lain hanyalah manusia seperti kamu, yang bermaksud hendak menjadi seorang yang lebih tinggi dari kamu. Dan kalau Allah menghendaki, tentu Dia mengutus beberapa orang malaikat. Belum pernah kami mendengar (seruan yang seperti) ini pada masa nenek moyang kami yang dahulu. Ia tidak lain hanyalah seorang laki-laki yang berpenyakit gila, maka tunggulah (sabarlah) terhadapnya sampai suatu waktu." Nuh berdoa: "Ya Tuhanku, tolonglah aku, karena mereka mendustakan aku." Lalu Kami wahyukan kepadanya: "Buatlah bahtera di bawah penilikan dan petunjuk Kami, maka apabila perintah Kami telah datang dan tannur telah memancarkan air, maka masukkanlah ke dalam bahtera itu sepasang dari tiap-tiap (jenis), dan (juga) keluargamu, kecuali orang yang telah lebih dahulu ditetapkan (akan ditimpa adzab) di antara mereka. Dan janganlah kamu bicarakan dengan Aku tentang orang-orang yang dzalim, karena sesungguhnya mereka itu akan ditenggelamkan.

${ }^{25}$ Maryam (19): 42-48:

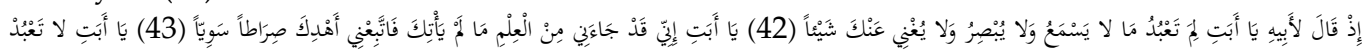

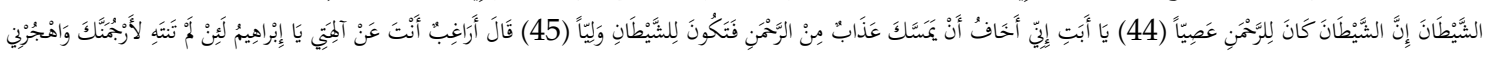

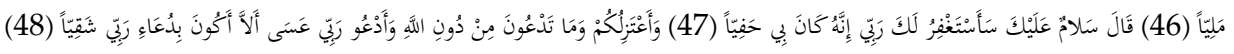

Artinya: Ingatlah ketika ia berkata kepada bapaknya: "Wahai bapakku, mengapa kamu menyembah sesuatu yang tidak mendengar, tidak melihat dan tidak dapat menolong kamu sedikit pun? Wahai bapakku, sesungguhnya telah datang kepadaku sebahagian ilmu pengetahuan yang tidak datang kepadamu, maka ikutilah aku, niscaya aku akan menunjukkan kepadamu jalan yang lurus. Wahai bapakku, janganlah kamu menyembah syaitan. Sesungguhnya syaitan itu durhaka kepada Tuhan Yang Maha Pemurah. Wahai bapakku, sesungguhnya aku khawatir bahwa kamu akan ditimpa adzab dari Tuhan Yang Maha Pemurah, maka kamu menjadi kawan bagi syaitan". Berkata bapaknya: "Bencikah kamu kepada tuhan-tuhanku, hai Ibrahim? Jika kamu tidak berhenti, maka niscaya kamu akan kurajam, dan tinggalkanlah aku buat waktu yang lama". Berkata Ibrahim: "Semoga keselamatan dilimpahkan kepadamu, aku akan meminta ampun bagimu kepada Tuhanku. Sesungguhnya Dia sangat baik kepadaku. Dan aku akan menjauhkan diri dari padamu dan dari apa yang kamu seru selain Allah, dan aku akan berdoa kepada Tuhanku, mudah-mudahan aku tidak akan kecewa dengan berdoa kepada Tuhanku".

${ }^{26}$ Al-Anbiya (21);52 dan 53.

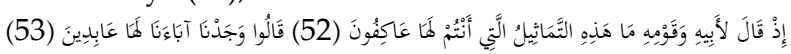

Artinya: (Ingatlah), ketika Ibrahim berkata kepada bapaknya dan kaumnya: "Patung-patung apakah ini yang kamu tekun beribadah kepadanya? Mereka menjawab: "Kami mendapati bapak-bapak kami menyembahnya" 
Mereka melanjutkan sesembahan patung yang sudah menjadi tradisi bapak dan nenek mereka.

Ketiga, kisah nabi Musa AS dan Harun menghadapi pembangkangan dari Fir'aun, Haman dan Qarun termaktub dalam surah Yunus (10): 75 - 78. ${ }^{27}$ Inti dari ayat ini adalah perintah menyembah Allah. Umat protes karena diminta berpaling atau meninggalkan dari mengerjakan apa yang mereka dapat dikerjakan nenek moyang mereka.

Keempat, kisah penolakan kaum Samud terhadap nabi Saleh AS dan Hud AS, sebagaimana disebutkan dalam surah Hud (11); 62.28 Berdasarkan ayat ini, alasan penolakan adalah karena disuruh meninggalkan sesembahan mereka yang mereka dapat/warisi dari bapak-bapak mereka.

Kelima, penolakan terhadap nabi Syuaib oleh kaum (penduduk) Madyan yang melakukan curang timbangan, sebagaimana disebut dalam surah Hud (11); 84. Tentang penolakannya disebut dalam surah Hud (11);87.29 Inti dan alasan penolakan

\footnotetext{
27 Yunus (10): $75-78$,

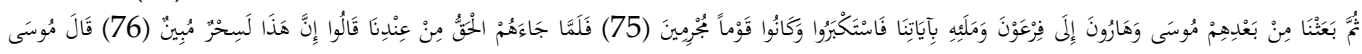

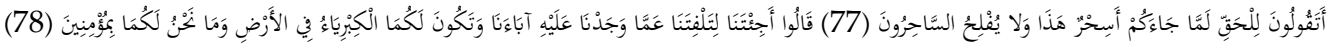

Artinya; Kemudian sesudah rasul-rasul itu, Kami utus Musa dan Harun kepada Firaun dan pemuka-pemuka kaumnya, dengan (membawa) tanda-tanda (mukjizat-mukjizat) Kami, maka mereka menyombongkan diri dan mereka adalah orang-orang yang berdosa. Dan tatkala telah datang kepada mereka kebenaran dari sisi Kami, mereka berkata: "Sesungguhnya ini adalah sihir yang nyata". Musa berkata: "Apakah kamu mengatakan terhadap kebenaran waktu ia datang kepadamu, sihirkah ini?" padahal ahli-ahli sihir itu tidaklah mendapat kemenangan". Mereka berkata: "Apakah kamu datang kepada kami untuk memalingkan kami dari apa yang kami dapati nenek moyang kami mengerjakannya, dan supaya kamu berdua mempunyai kekuasaan di muka bumi? kami tidak akan mempercayai kamu berdua.

${ }^{2828}$ Hud (11); 62,

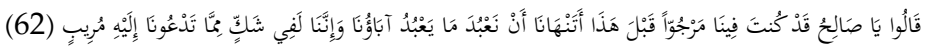

Artinya: Kaum Tsamud berkata: "Hai shaleh, sesungguhnya kamu sebelum ini adalah seorang di antara kami yang kami harapkan, apakah kamu melarang kami untuk menyembah apa yang disembah oleh bapak-bapak kami? dan sesungguhnya kami betul-betul dalam keraguan yang menggelisahkan terhadap agama yang kamu serukan kepada kami.

${ }^{29}$ surah Hud (11); 84. Penolakannya hud ayat 87,

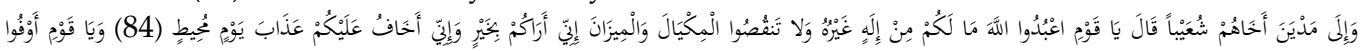

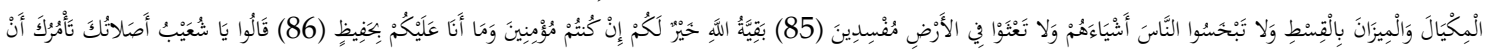

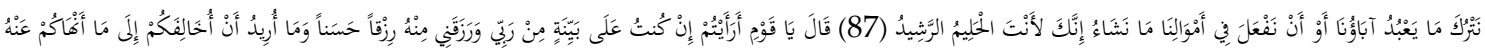

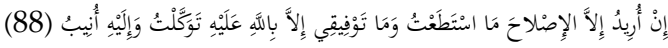

Artinya: Dan kepada (penduduk) Mad-yan (Kami utus) saudara mereka, Syu'aib. Ia berkata: "Hai kaumku, sembahlah Allah, sekali-kali tiada Tuhan bagimu selain Dia. Dan janganlah kamu kurangi takaran dan timbangan, sesungguhnya aku melihat kamu dalam keadaan yang baik (mampu) dan sesungguhnya aku khawatir terhadapmu akan adzab hari yang membinasakan (kiamat). Dan Syu'aib berkata: "Hai kaumku, cukupkanlah takaran dan timbangan dengan adil, dan janganlah kamu merugikan manusia terhadap hak-hak mereka dan janganlah kamu membuat kejahatan di muka bumi dengan membuat kerusakan. Sisa (keuntungan) dari Allah adalah lebih baik bagimu jika kamu orang-orang yang beriman. Dan aku bukanlah seorang penjaga atas dirimu." Mereka berkata: "Hai Syu'aib, apakah agamamu yang menyuruh kamu agar kami meninggalkan apa yang disembah oleh bapak-bapak kami atau melarang kami memperbuat apa yang kami kehendaki tentang harta kami. Sesungguhnya kamu adalah orang yang sangat penyantun lagi berakal." Syu'aib berkata: "Hai kaumku, bagaimana pikiranmu jika aku mempunyai bukti yang nyata dari Tuhanku dan dianugerahi-Nya aku daripada-Nya rezeki yang baik (patutkah aku menyalahi perintah-Nya)? Dan aku tidak berkehendak menyalahi kamu (dengan 
adalah karena disuruh meninggalkan sesembahan dan praktek dagang yang mereka lakukan sebagai warisan atau mengikuti bapak-bapak mereka, yakni dagang dengan mengurangi timbangan.

Keenam, berisi perintah kepada nabi Muhammad saw agar tidak ragu mengubah sembahan nenek moyang Arab pra Islam, sebagaimana disebut dalam surah Hud (11): 109.30 Ayat ini juga menunjukkan bagaimana masyarakat Arab praIslam yang sudah biasa mengikuti tradisi nenek moyang mereka, kemudian diminta oleh nabi Muhammad saw agar mereka meninggalkannya.

Sejalan dengan apa yang ditulis di atas, ketika diperintah kepada orang yang membantah keesaan Allah, untuk ikut apa yang diturunkan Allah, dijawab tidak, tetapi akan ikut apa yang didapat dari bapak-bapak mereka, sebagaimana disebutkan dalam surah Luqman (31); 21. ${ }^{31}$ Intinya, mereka menolak karena diminta meninggalkan apa yang dilakukan bapak dan kakek mereka. Dengan kata lain, mereka mengikut dan melaksanakan apa yang dilaksanakan bapak dan kakek mereka. Mereka menolak perubahan.

Inti yang sama tergambar dalam surah Saba (34); $43^{32}$ dan Al-Syuara (26); 70 sd $74{ }^{33}$ mereka menolak karena diminta meninggalkan apa yang sudah menjadi

mengerjakan) apa yang aku larang. Aku tidak bermaksud kecuali (mendatangkan) perbaikan selama aku masih berkesanggupan. Dan tidak ada taufik bagiku melainkan dengan (pertolongan) Allah. Hanya kepada Allah aku bertawakal dan hanya kepada-Nya-lah aku kembali.

${ }^{30}$ Hud (11): 109

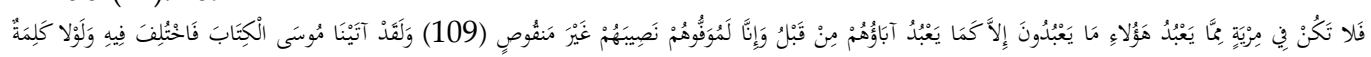

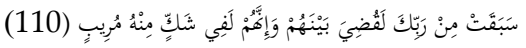

Artinya: Maka janganlah kamu berada dalam keragu-raguan tentang apa yang disembah oleh mereka. Mereka tidak menyembah melainkan sebagaimana nenek moyang mereka menyembah dahulu. Dan sesungguhnya Kami pasti akan menyempurnakan dengan secukup-cukupnya pembalasan (terhadap) mereka dengan tidak dikurangi sedikit pun. Dan sesungguhnya Kami telah memberikan Kitab (Taurat) kepada Musa, lalu diperselisihkan tentang Kitab itu. Dan seandainya tidak ada ketetapan yang telah terdahulu dari Tuhanmu, niscaya telah ditetapkan hukuman di antara mereka. Dan sesungguhnya mereka (orang-orang kafir Mekah) dalam keraguan yang menggelisahkan terhadap Al Qur'an.

${ }^{31}$ Luqman (31); 21

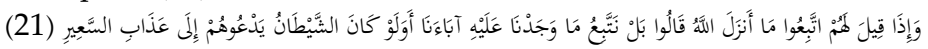

Artinya: Dan apabila dikatakan kepada mereka: "Ikutilah apa yang diturunkan Allah". Mereka menjawab: "(Tidak), tapi kami (hanya) mengikuti apa yang kami dapati bapak-bapak kami mengerjakannya". Dan apakah mereka (akan mengikuti bapak-bapak mereka) walaupun syaitan itu menyeru mereka ke dalam siksa api yang menyala-nyala (neraka)?

32 Saba (34); 43

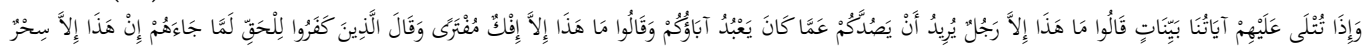
(43)

Artinya: Dan apabila dibacakan kepada mereka ayat-ayat Kami yang terang, mereka berkata: "Orang ini tiada lain hanyalah seorang laki-laki yang ingin menghalangi kamu dari apa yang disembah oleh bapak-bapakmu", dan mereka berkata: "(Al Qur'an) ini tidak lain hanyalah kebohongan yang diadaadakan saja". Dan orang-orang kafir berkata terhadap kebenaran tatkala kebenaran itu datang kepada mereka: "Ini tidak lain hanyalah sihir yang nyata".

${ }^{33}$ Al-Syuara (26); 70 sd 74.

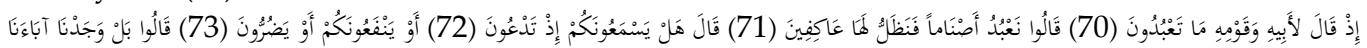
كَذَلِكَ يَفْعُونَن (74)

Artinya: Ketika ia berkata kepada bapaknya dan kaumnya: "Apakah yang kamu sembah?". Mereka menjawab: "Kami menyembah berhala-berhala dan kami senantiasa tekun menyembahnya". 
sesembahan dan tradisi bapak-bapak mereka. Jadi mereka menolak karena diminta meninggalkan apa yang menjadi sembahan dan tradisi bapak-bapak mereka.

Dari sejumlah ayat yang memberitakan penolakan umat terhadap risalah para nabi terdapat tiga alasan inti, yakni;

1. Risalah kenabian memerintahkan untuk mengubah sesembahan dari sesembahan yang sudah dilakukan bapak dan kakek mereka menjadi hanya Allah yang disembah

2. Risalah kenabian memerintahkan untuk mengubah dari dan meninggalkan apa yang sudah biasa mereka lakukan mengikuti apa yang dilakukan nenek moyang mereka

3. Risalah kenabian memerintahkan untuk mengubah dari dan meninggalkan perilaku mereka mengurangi timbahan mengikuti apa yang sudah menjadi tradisi nenek moyang

Dengan ringkas, pesan para nabi yang ditolak umat adalah pesan perubahan, pesan agar umat berubah. Para umat menolak perintah untuk berubah. Umat ingin mempertahankan apa yang sudah mapan, Umat ingin mempertahankan apa yang telah menjadi tradisi. Umat ingin mempertahankan apa yang telah menjadi kebiasaan mereka mengikuti apa yang sudah menjadi kebiasaan (tradisi) dan sesembahan bapak dan nenek moyang mereka.

\section{Pro dan Kontra Kelahiran UUP}

UU No. 1 tahun 1974 merupakan Undang-undang pertama yang berisi materi perkawinan. Kelahiran dan penetapan UU ini pun juga ada pro dan kontra, ada yang setuju bahkan mendesak, ada yang menolak. Pihak yang pro sudah muncul lama, baik secara organisasi maupun perorangan. Keinginan dan tuntutan dari beberapa organisasi, khususnya organisasi-organisasi wanita, membicarakannya sampai ke dewan Rakyat (Volksroad). Untuk mencatat di antaranya, Kongres wanita Indonesia tahun 1928, membahas keburukan-keburukan yang terjadi dalam perkawinan menurut Islam, ${ }^{34}$ yakni akibat buruk dari perkawinan anak-anak (di bawah umur), akibat kawin paksa (waji mujbir), akibat poligami, dan akibat talak sewenang-wenang dari suami. ${ }^{35}$ Secara individu, jauh sebelum muncul tuntutan orgnisasi, Raden Ajeng Kartini (18791904) di Jawa Tengah dan Rohana Kudus di Minang Kabau, Sumatera Barat, ${ }^{36}$ adalah

Berkata Ibrahim: "Apakah berhala-berhala itu mendengar (doa) mu sewaktu kamu berdoa (kepadanya)? atau (dapatkah) mereka memberi manfaat kepadamu atau memberi mudarat? Mereka menjawab: "(Bukan karena itu) sebenarnya Kami mendapati nenek moyang kami berbuat demikian".

${ }^{34}$ Apa yang dimaksud dengan menurut hukum Islam di sini adalah menurut praktek orangorang Islam Indonesia yang didasarkan pada konsep-konsep kitab fikih konvensional.

${ }^{35}$ Arso Sosroatmodjo dan A. Wasit Aulawi, Hukum Perkawinan di Indonesia, cet. ke 2 (Jakarta: Bulan Bintang, 1978), hlm. 9.

${ }^{36}$ Lihat Barbara N. Ramusack and Sharon Sievers, Women In Asia (Indianapolis: Indiana University Press, 1988), hlm. 100. Rohana Kudus mulai menulis pandangan-pandangannya dalam bentuk surat yang dikirm ke jurnal, yang akhirnya disatukan dan dibukukan oleh suami dan bapaknya dalam buku yang berjudul, Sunting Melayu (Malayan Headres). Fokus utama dalam tulisan-tulisannya adalah akibat buruk dari praktek poligami. Dalam buku The Indonesian Women, Stuers mencatat 1900 sebagai tahun kelahiran Rohana Kudus. Sejumlah penulis menyetujui tahun 1900 sebagai tahun lahir Rohana Kudus, tetapi banyak juga penulis lain yang tidak setuju dengan tahun ini. Deliar Noer, misalnya, menulis 13 Desember 1900 sebagai tahun lahirnya, sementara Jeanne Cuisinier menulis tahun 1903. Lihat Cora 
tokoh yang telah lama mengkritik keburukan-keburukan yang diakibatkan oleh perkawinan di bawah umur, perkawinan paksa, poligami dan talak. ${ }^{37}$

Pada kasus yang lebih khusus, tentang poligami, Puteri Indonesia bekerja sama dengan Persaudaraan Isteri, Persatuan Isteri dan Wanita Sejati, dalam sebuah pertemuan pada tanggal 13 Oktober 1929 di Bandung, membuat ketetapan tentang larangan poligami. Pertemuan di Bandung ini membicarakan dua hal pokok, yakni poligami dan pelacuran. Pada bulan Juni 1931 di Jakarta, Kongres Isteri Sedar memperkuat resolusi larangan poligami yang ditetapkan beberapa organisasi wanita dan ditepakan pada tanggal 13 Oktober 1929.38 Bahkan lahirnya BP4 (Badan Penasehat Perkawinan dan Penyelesaian Perceraian), pada tahun 1950-an pun didorong oleh akibat-akibat negatif dari perkawinan yang secara umum dapat dikategorikan menjadi tiga, yakni 1.praktek perkawinan di bawah umur (perkawinan anak-anak), 2.terjadinya perceraian yang semena-mena (talak), dan 3.poligami yang tidak bertanggung jawab. Akibatnya, angka perceraian menjadi cukup tinggi, yakni 50-60\% dari angka perkawinan. Bahkan satu sumber menyebut angka perceraian di awal pembentukan BP4 tahun 1954, mencapai angka $60-80 \% .{ }^{39}$ Akibat selanjutnya banyak anak-anak yang menjadi korban, dan tidak sedikit istri yang tidak tertentu nasibnya karena para suami meninggalkan istri dan anak-anaknya begitu saja tanpa pesan, kesan dan tanggung jawab. Maka tugas BP4 adalah membantu menyelesaikan agar para mantan isteri dan anak-anak yang ditinggal suami/ayah mempunyai status hukum yang jelas. ${ }^{40}$

Sementara pihak yang kontra, pihak yang memberikan tanggapan negatif terhadap rencana kehadiran Undang-undang Perkawinan, juga datang dari organisasiorganisasi Muslim dan perseorangan. Sarekat Isteri Jakarta pada pertemuannya di Jakarta 1 Minggu setelah Kongres Isteri Sedar (Juni 1931), di mana kongres Isteri Sedar membuat resolusi tentang larangan Poligami, memberikan tanggapan negatif terhadap tuntutan Isteri Sedar tersebut. Hasil pertemuan Sarekat Isteri Jakarta adalah memprotes keputusan (resolusi) larangan poligami tersebut. Demikian juga respon negatif muncul

Vreede-de Stuers, “The Life of Rankayo Rohmah El-Yunusia: The Fact and The Image), dalam Elsbeth Lecher-Scholten and Anke Niehof, eds. Indonesian Women in Focus: Past and Present Notions (Dordrecht: Foris Publication, 1987), hlm. 52, 57.

37Stuers, The Indonesian Women, hlm. 53.

${ }^{38}$ Nurlena Rifai, "Muslim Women in Indonesia`s Politics: An Historical Examination of the Political Career of Aisyah Aminy", (Montreal: Tesis MA pada McGill University 1993), hlm. 32.

${ }^{39}$ Lihat wikipedia.org. subjek BP4. Akses Senin 23 Maret 2020.

${ }^{40}$ Demikian disampaikan Dra. Hj. Zubaidah Mukhtar pada seminar tentang "Efektifitas penyelenggaraan Suscantan di DKI Jakarta", yang di selenggarakan di BALI TAMAS (Balai Penelitian Agama dan Kemasyarakatan) DEPAG RI. Pada hari Selasa, 3 Maret 1999, seperti ditulis H.U. Pelita, 4 Maret 1999, hlm. 2. Awalnya BP4 merupakan kependekan dari (Badan Penasihat Perkawinan dan Penyelesaian Perceraian). Sebelum adanya UUP, ada kerjasama antara Pengadilan Agama (PA) dan BP4, yaitu sebelum ke PA suami istri yang akan bercerai hendaknya ke BP4 terlebih dahulu untuk didamaikan. Bila tidak berhasil yang bersangkutan dikirim ke Pengadilan Agama oleh BP4. Tetapi dengan UUP Pasal 39 ayat (1): "Perceraian hanya dapat dilakukan di depan sidang pengadilan yang berwenang setelah pengadilan yang bersangkutan berusaha dan tidak berhasil mendamaikan kedua belah pihak," maka masalah perceraian menjadi kewenangan Pengadilan Agama. Konsekuensinya nama BP4 diubah kepanjangannya berdasarkan SK Menag No.30 tahun 1970 menjadi: “Badan Penasihat Perkawinan, Perselisihan dan Perceraian". Kemudian berganti menjadi Badan Penasihatan Pembinaan dan Pelestarian Perkawina (BP4). 
dari Ratna Sari, Ketua Persatruan Muslim Indonesia (Permi), yang disampaikan pada Kongres seluruh wanita Indonesia di Jakarta pada tahun 1935. Ratna Sari tidak setuju kalau poligami dianggap merendahkan status wanita, dengan alasan bahwa Islam hanya membolehkan poligami, bukan menganjurkan. Karena itu, pembolehan poligami menurut Islam disesuaikan dengan tuntutan yang ada, misalnya dalam kondisi terlalu banyak jumlah wanita. Menjadi isteri kedua, ketiga atau keempat masih lebih baik bagi seorang wanita daripada melakukan praktek pelacuran (prostitusi), demikian Ratna Sari. ${ }^{41}$

Demikian juga pada saat pembahasan RUU di DPR sejumlah respons negatif muncul, baik melalui perseorangan maupun organisasi. Di antara kritik tersebut misalnya dapat dicatat pandangan Asma Sjahroni, wakil dari fraksi Persatuan Pembangunan (FPP), yang menyebut RUU tersebut menjadi indikasi pencabutan hukum perkawinan Adat dan Hukum Perkawinan Islam, yang dianut oleh kebanyakan masyarakat Indonesia. Dalam ungkapannya sendiri:

Demikianlah kami berkesimpulan RUU Perkawinan ini telah mengambil alih atau meresipir BW dan HOCI, yang hanya berlaku untuk golongan Eropa dan Timur Asing dan orang Kristen Indonesia saja. Sebaliknya Hukum Perkawinan Adat dan Hukum Perkawinan Islam yang dianut dan dilakukan oleh sebagian terbesar rakyat Indonesia dikeluarkan begitu saja. ${ }^{42}$

Lebih dari itu, sejumlah demonstran di jalanan dengan seruan "Allähu akbar" mengutuk rancangan itu sebagai perbuatan sekular. Bahkan pada tanggal 27 September 1973 telah terjadi keributan di dalam gedung DPR oleh mahasiswa.

Adapun rancangan pasal-pasal yang dianggap mendapat kritik paling keras dari kaum Muslim Indonesia diantaranya adalah rancangan aturan tentang pencatatan sebagai syarat sah pernikahan (pasal 2 ayat (1) dan pasal 44), bahwa poligami harus mendapat izin dari pengadilan (pasal 3, 4 dan 5), pembatasan usia minimal boleh nikah, 21 tahun untuk laki-laki dan 18 tahun untuk perempuan (pasal 6), perkawinan antara pemeluk agama (campuran) (pasal 11), pertunangan (pasal 13), perceraian harus dengan izin pengadilan (pasal 40), pengangkatan anak (pasal 62).

Dalam masalah pencatatan misalnya, ditetapkan bahwa pencatatan merupakan syarat sah pernikahan. Aturan ini dianggap bertentangan dengan ajaran Islam yang menganggap pernikahan sebagai satu ikatan yang sangat sakral dan penuh dengan nuansa agama. Demikian juga aturan bahwa untuk poligami dan perceraian hanya dapat dilakukan setelah mendapat izin dari pengadilan, dikategorikan sebagai aturan yang bertentangan dengan ajaran Islam. Lebih-lebih rancangan yang akan membolehkan seorang wanita muslim kawin dengan laki-laki non muslim. ${ }^{43}$ Salah satu komentar terhadap rencana aturan batas minimal boleh nikah misalnya muncul dari Asam Sjahroni, yang melihatnya sebagai aturan yang tidak mengakar pada kebutuhan

${ }^{41}$ Nur Lena Rifai, “Muslim Women In Indonesia`s Politics”, hlm. 32.

${ }^{42}$ Risalah DPR XI, 18 September 1973, seperti dikutip oleh Abdul Hadi, Draf Disertasi, hlm. 79.

${ }^{43}$ M. B. Hooker, Islamic Law In South-East Asia, (Oxford, New York, Singapore; Oxford University Press, 1984), hlm. 272.

ADHKI: Journal of Islamic Family Law 
situasi Indonesia. Menurutnya, larangan perkawinan di bawah umur malah justru akan memberikan peluang tumbuh suburnya pergaulan bebas. ${ }^{44}$

Demikianlah secara singkat gambaran perdebatan (kontropersi) yang terjadi sebelum dan semasa pembahasan rancangan undang-undang Perkawinan, di dalam maupun di luar gedung DPR sampai akhirnya menjadi undang-undang No. 1 tahun $1974 .{ }^{4}$

Dari penjelasan di atas dapat dicatat 3 sebagai alasan penolakan terhadap lahir dan ditetapkan UUP. Pertama, kelahiran UUP adalah pencabutan hukum perkawinan Adat dan Hukum Perkawinan Islam, yang dianut oleh kebanyakan masyarakat Indonesia. Kedua, rencana aturan batas minimal boleh nikah adalah aturan yang tidak mengakar pada kebutuhan situasi Indonesia. Larangan perkawinan di bawah umur malah justru akan memberikan peluang tumbuh suburnya pergaulan bebas. Ketiga, Islam hanya membolehkan poligami, bukan menganjurkan. Karena itu, pembolehan poligami menurut Islam disesuaikan dengan tuntutan. Menjadi isteri kedua, ketiga atau keempat masih lebih baik bagi seorang wanita daripada melakukan praktek pelacuran (prostitusi).

Adapun perbedaan antara kelompok pro dan kontra dapat dijelaskan, kelompok pro (pengusul dan pengusung) lahir dan ditetapkannya UUP berbicara fakta kejelekan-kejelekan yang sudah jelas terjadi di masyarakat Indonesia. Maka usulan lahir dan ditetapkan UUP adalah rangka menyelesaikan masalah-masalah tersebut. Sementara kelompok kontra (kelompok yang menolak lahir dan ditetapkannya) UUP berbicara normatif perkawinan, tidak berbicara fakta apa yang terjadi di sekeliling mereka.

\section{Relevansi Penolakan Misi Kenabian dengan Hukum Keluarga Kontemporer}

Dalam rangka memperlihatkan relevansi antara penolakan misi kenabian oleh umat dan penolakan kelahiran dan penetapan UUP oleh masyarakat Indonesia, dapat dijelaskan berikut.

Sebagaimana dicatat sebelumnya, secara rinci ada tiga sebab mengapa umat menolak risalah kenabian, yakni;

1. risalah kenabian mengubah sesembahan dari sesembahan yang sudah dilakukan bapak dan kakek mereka menjadi hanya Allah yang disembah,

2. risalah kenabian mengubah dari dan meninggalkan apa yang sudah biasa mereka lakukan mengikuti apa yang dilakukan nenek moyang mereka,

3. risalah kenabian mengubah dari dan meninggalkan perilaku mereka mengurangi timbahan mengikuti apa yang sudah menjadi tradisi nenek moyang.

\footnotetext{
${ }^{44}$ Menurut Asma ditemukan alasan/dasar yang cukup kompleks kenapa terjadi pernikahan dini, yakni antara lain: alasan ekonomi, menjaga agar tidak terjadi hubungan di luar nikah, alasan kepentingan keluarga dan lain-lain. Lihat Risalah DPR RI, 18 September 1973, seperti dicatat Abdul Hadi Draf Disertasi, hlm. 79 .

${ }^{45}$ Lebih jelas dan rinci tentang pro dan kontra kelahiran dan penetapan UU No. 1 tahun 1974 tentang Perkawinan dapat dilihat Khoiruddin, Status Wanita di Asia Tenggara: Studi terhadap Perundangundangan Perkawinan Muslim Kontemporer Indonesia dan Malaysia. (Jakarta: INIS, 2002).
} 
Inti dari tiga alasan tersebut adalah satu, yakni pesan perubahan, agar berubah. Umat menolak perintah untuk berubah. Umat ingin mempertahankan apa yang sudah mapan, Umat ingin mempertahankan apa yang telah menjadi kebiasaan (tradisi), mengikuti apa yang sudah menjadi kebiasaan (tradisi) dan sesembahan bapak dan nenek moyang mereka.

Sementara alasan penolakan terhadap lahir dan ditetapkan UUP juga ada tiga. Pertama, kelahiran UUP adalah pencabutan Hukum Perkawinan Adat dan Hukum Perkawinan Islam, yang dianut oleh kebanyakan masyarakat Indonesia. Kedua, rencana aturan batas minimal boleh nikah adalah aturan yang tidak mengakar pada kebutuhan situasi Indonesia. Larangan perkawinan di bawah umur malah justru akan memberikan peluang tumbuh suburnya pergaulan bebas. Ketiga, pembolehan poligami menurut Islam adalah bersifat kontekstual, sesuai dengan tuntutan. Inti dari tiga alasan tersebut adalah juga penolakan terhadap perubahan. Masyarakat belum rela berubah.

Dengan demikian terlihat relevansi antara penolakan risalah kenabian oleh umat di satu sisi, dan penolakan kelahiran dan penetapan UUP oleh masyarakat Indonesia pada sisi lain. Intinya, sama-sama menolak berubah dan sama-sama ingin mempertahankan kemapanan.

Relevansi lain yang dapat dicatat, alasan menolakan adalah karena kurang paham. Umat belum paham bahwa ajaran yang dibawa para nabi adalah ajaran kebenaran yang harus diterima untuk keselamatan hidup dunia dan akhirat, keselamatan seluruh umat manusia (kemanusiaan). Masyarakat Indonesia kurang atau tidak paham bahwa UUP mempunyai status yang lebih otoritatif daripada fikih konvensional yang mereka sebut hokum Islam. Ungkapan lain, masyarakat Indonesia belum atau kurang paham bahwa apa yang mereka sebut hokum Islam adalah hasil pemikiran mujtahid terhadap nash, sama dengan fikih, fatwa, tafsir, yurisprudensi dan undang-undang, termasuk UUP (kodifikasi). Bahkan UUP lebih otoritatif daripada fikih, fatwa, tafsir, yurisprudensi, sebab UUP merupakan hasil ijtihad banyak ahli ('âlim, 'ulamâ') dan banyak pemimipin (râ'is, ruasâ'). Ahli yang terlibat dalam penetapan UUP adalah ahli dari berbagai bidang keilmuan. Kesepakatan para ahli dan para pemimpin ini dalam bahasa Ushul Fikih adalah ijmâ', sumber ajaran Islam ketiga setelah al-Qur'an dan sunnah nabi Muhammad saw. Sementara fikih, fatwa, yurisprudensi adalah hasil ijtihad individu/perorangan (fardi). Meskipun ada fatwa kolektif, tetapi jumlah mujtahid yang terlibat dalam penetapan fatwa tetap sangat terbatasi dibandingkan dengan ahli dan pemimpin yang terlibat dalam merumuskan dan menetapkan UUP. ${ }^{46}$

Tugas para nabi sepanjang hayatnya adalah memahamkan umat tentang kebenaran ajaran yang mereka bawa. Faktanya, banyak nabi yang berhasil, namun ada juga yang tidak. Kaitan dengan UUP maka tugas para peminat, pemerhati, pegiat dan garda depan Hukum Keluarga adalah memahamkan, mensosialisasikan dan mempercayakan masyarakat Indonesia tentang status UUP. Bahwa UUP dan

\footnotetext{
${ }^{46}$ Khoiruddin Nasution, “Dasar Wajib Mematuhi Undang-Undang Perkawinan (UUP): Studi Pemikiran Muhammad 'Abduh", dalam ADHKI: Journal of Islamic Family Law, Vol. 1, Nomor 1, Juni 2019 (Januari-Juni 2019), hlm. 1-16. URL: http://jurnal.adhkiindonesia.or.id/index.php/ADHKI/article/view/8/1.
} 
peraturan terkait merupakan syari'ah Indonesia. Bahwa UUP dan peraturan terkait merupakan hokum Islam Indonesia. Bahwa UUP dan peraturan terkait merupakan fikih Indonesia. Bahwa UUP dan peraturan terkait merupakan ijmâ' yang wajib dipatuhi. Sehingga akhirnya masyarakat Indonesia yakin, percaya, memberikan sikap positif, mematuhi dan melaksanakan aturan yang tertulis dalam UUP dan peraturan terkait.

\section{Kesimpulan}

Apa yang dapat dicatat sebagai kesimpulan dari bahasan tulisan ini adalah ditemukan relevansi antara alasan penolakan risalah kenabian oleh umat di satu sisi, dengan alasan penolakan masyarakat Indonesia terhadap UUP dan peraturan terkait di sisi lain. Relevansi yang ditemukan adalah dua-duanya ditolak karena membawa ajakan perubahan. Umat menolak perubahan, sama dengan masyarakat Indonesia juga menolak perubahan. Umat menginginkan kemapanan, sama dengan masyarakat Indonesia menginginkan kemapanan. Latar belakang penolakan adalah kurang atau tidak paham akan perubahan yang dibawa. Maka tugas para nabi sepanjang hidupnya adalah memahamkan umat. Sebagian besar nabi berhasil memahamkan dan akhirnya umat menerima pesan risalah kenabian, tetapi ada juga yang tidak berhasil dipahamkan. Sejalan dengan tugas para nabi, maka tugas para peminat, pemerhati, pemikir, dan pakar Hukum Keluarga Islam Indonesia adalah memahamkan masyarakat Indonesia akan status UUP. Bahwa UUP dan peraturan terkait adalah syariah Islam Indonesia. Bahwa UUP dan peraturan terkait adalah hokum Islam Indonesia. Bahwa UUP dan peraturan terkait sama statusnya dengan fikih, fatwa, yurispruden dan tafsir, sama-sama hasil ijtihad, sama-sama hasil pemikiran, samasama hasil istinbath hokum. Bahwa UUP malah hasil ijma, sementara fikih, fatwa, yurisprudensi adalah hasil ijtihad individu (fardi). Meskipun ada fatwa kolektif, tetapi jumlah mujtahid yang terlibat tetap sangat terbatasi dibandingkan dengan ahli yang terlibat dalam merumuskan dan menetapkan UUP.

\section{Daftar Pustaka}

Abdul Hakim Siregar, "Psikologi Kenabian dalam Menghidupkan Kepribadian Diri", Wahana Inovasi, Vol.3 No.2 (Juli-Des 2014), hlm. 274-287.

Arif Nuh Safri, "Otentisitas Risalah Kenabian (Pluralisme dan Kemanusiaan)", ESENSIA: Jurnal FUPI, UIN Suka Yogyakarta, Vol. XIII No. (1 Januari 2012), hlm. 167-186.

Arso Sosroatmodjo dan A. Wasit Aulawi, Hukum Perkawinan di Indonesia, cet. ke 2. Jakarta: Bulan Bintang, 1978

Barbara N. Ramusack and Sharon Sievers, Women In Asia. Indianapolis: Indiana University Press, 1988.

Cora Vreede-de Stuers, "The Life of Rankayo Rohmah El-Yunusia: The Fact and The Image), dalam Elsbeth Lecher-Scholten and Anke Niehof, eds. Indonesian Women in Focus: Past and Present Notions (Dordrecht: Foris Publication, 1987), hlm. 52, 57.

Eni Zulaiha, "Fenomena Nabi dan Kenabian dalam Perspektif Alquran", dalam AlBayan: Jurnal Studi Al-Qur'an dan Tafsir 1, 2 (Desember 2016), hlm. 149-164.

H.U. Pelita, 4 Maret 1999, hlm. 2. 
Hamim Ilyas, “Islam Risalah Rahmat dalam al-Qur'an (Tafsir Q.S. Al-Anbiya (21):107”, Hermeneia: Jurnal Kajian Islam Interdisipliner, Vol. 6, No. 2 (Juli-Desember 2017).

Khoiruddin Nasution, "Dasar Wajib Mematuhi Undang-Undang Perkawinan (UUP): Studi Pemikiran Muhammad 'Abduh", dalam ADHKI: Journal of Islamic Family Law, Vol. 1, Nomor 1, Juni 2019 (Januari-Juni 2019), hlm. 1-16. URL: http://jurnal.adhkiindonesia.or.id/index.php/ADHKI/article/view/8/1.

Khoiruddin Nasution, Status Wanita di Asia Tenggara: Studi terhadap Perundang-undangan Perkawinan Muslim Kontemporer Indonesia dan Malaysia. Jakarta: INIS, 2002.

M. B. Hooker, Islamic Law in South-East Asia. Oxford, New York, Singapore; Oxford University Press, 1984.

Murtadha Muthohhari, Falsafah Kenabian, terj. Ahsin Muhammad, cet ke-1. Jakarta: Pustaka Risalah, 1991.

Nurlena Rifai, “Muslim Women in Indonesia`s Politics: An Historical Examination of the Political Career of Aisyah Aminy". Montreal: Tesis MA pada McGill University 1993

Salamah Noorhidayati, "Menguak Fakta Kenabian Maryam AS”, YIN YANG. Vol. 9 No. 1 (Januari-Juni 2014), hlm. 19-36.

Siti Malaiha Dewi, "Kontektualisasi Misi Risalah Kenabian dalam Menangkal Radikalisme", FIKRAH: Jurnal Ilmu Aqidah dan Studi Keagamaan, Volume 3, No.

2, (Desember 2015), hlm. 349-369.

Wikipedia.org. subjek BP4. Akses Senin 23 Maret 2020.

Lisan al-'Arab, Abdullah ibn Mandhur. Beirut: Dar al-Sadir, t.t.), VI: 561.

Kamur Besar Bahasa Indonesia, Tim Perumus, ed ke-2. Jakarta: Balai Pustaka, 1994. 